\title{
Climate change, adaptation, and global jobs: Lessons and urgent policy options for Africa
}

\author{
A. M. Ogaboh Agba ${ }^{a^{*}}$, John J. Akpanudoedehe ${ }^{b}$, Felix E. Ojong ${ }^{\mathrm{a}}$, Michael Sunday Agba ${ }^{\mathrm{c}}$ \\ ${ }^{a}$ Department of Sociology, University of Calabar, Nigeria \\ ${ }^{b}$ Chapel Villa, Uyo, Akwa Ibom State, Nigeria \\ ${ }^{c}$ Department of Public Administration, University of Calabar, Nigeria
}

\begin{abstract}
Climate change remains one of the world's greatest challenge in the $21^{\text {st }}$ century. It causes inevitable changes that alter human activities. Adaptation to climate change creates and at the same time limits opportunities that support human existence. While United States of America, Europe, China, India and other countries are maximizing the opportunities climate change adaptation offers especially in areas of green technology, energy and agriculture, that of Africa who are more vulnerable to climate change are complacent and at most show less commitment. As the negative impacts of climate change increases and livelihoods erode, and as jobs continue to disappear leading to conflicts and upheavals in Africa, governments across the continent need policy options that will enable them to mitigate and adapt to climate change while at the same time address the problem of unemployment and create new patterns of livelihood. This paper, therefore, explores options that support these objectives. It offered policy suggestions in green energy and agriculture where Africa have a comparative advantage over other nations, and which also has the capacity of employing 90 per cent of the continent's workforce. It makes suggestions on how Lake Chad and other water sources affected by climate change in Africa can be revived to support agricultural activities and hydropower industry as well as create green jobs. It advocated for investment in biofuel, wind and solar energies to create green jobs. The paper submits that if green jobs are created and agricultural activities supported conflicts associated with unemployment and migration will be reduced drastically.
\end{abstract}

Keywords: Climate change, adaptation, global jobs, unemployment, and policy.

\section{Introduction}

The continuous greenhouse gas emission causes inevitable and adverse effects on climate change. As human activities continue to impact negatively on the climate, global priority has been directed towards developing and implementing adaptation principles that will reduce gas emissions and mitigate climate change. These efforts are not without consequences on technology and global employment. Diverse and broad forms of knowledge are needed to develop materials and equipment that will advance the frontier of global adjustment to climate change. This knowledge drive and technology innovations are creating new employment opportunities while limiting opportunities that exist in old jobs (United Nations Framework Convention on Climate Change - UNFCCC, 2006). It also accounts for the dwindling foreign earnings of many nations especially crude oil-producing countries.

While many countries are addressing the challenges of climate change, most developing countries including that of Africa are not making concrete efforts to ensure that technologies created serve the greatest need of their vulnerable communities who have direct contact with the natural environment. As the ecological resource of these vulnerable communities are under threat, and their livelihoods erode due to climate change and technology innovations, ultimately social and political actions in Africa needs to be boosted through policy alternatives. Although a plethora of studies exists that established the links between climate change and employment, however, less consideration is

\footnotetext{
* Corresponding author.

E-mail address: ogabohagbagroup@yahoo.com (A. M. Ogaboh Agba)
} 
given to the impact of climate on specific jobs in Africa especially in the agricultural sector where the continent has a comparative advantage and majority of its workforce domiciled.

Gaps also exist on studies that proffer policy alternative that will enable Africa to adapt to climate change while at the same time create green jobs and ensure a smooth transition from old to new jobs. Again, as the unemployment rate occasioned by climate change continues to rise, limited studies exist on how this problem can be solved through concrete government policies that ensure the revival of lakes and other water sources that secures investment in the agriculture sector and hydropower industry as well as create jobs in these segments of the economy. Limited studies also exist on how government policies across Africa can create green jobs in wind, solar and biofuel industries thereby reduce the rising unemployment rate, curtail the high level of rural-urban migration and conflicts associated with unemployment in the continent. The concern of this paper, therefore, is to bridge these knowledge gaps. It will establish the links between climate change, adaptation, and global jobs as well as make policy suggests that will enable Africa countries to adjust to these global dynamics, create green jobs, reduce unemployment and conflicts associated with it, as well as ensure the livelihood of present and future generations.

\section{Meaning and menace of climate change}

Climate change is the alteration in the pattern of whether and correlate dynamics in the land surface, oceans, and ice sheets, that persist over a long-timescale usually 30 years and above (Australian Academy of Science, 2020). It is the periodic alteration of earth climate occasioned by a change in the atmosphere (Jackson, 2018). Climate change reflects natural phenomena like the eruption of volcanoes, human activities such as the burning of fossil fuels, change in land use. These factors among others contribute significantly to the increase in the atmospheric concentration of gases such as carbon dioxide, nitrous oxide (greenhouse gases - GHGs) and methane. The accumulation of these gases in the upper atmosphere provides a greenhouse that traps long-wave radiation and raises the atmospheric temperature. The advent of industrialisation has increased exponentially carbon dioxide emission from 280 parts per million (PPM) in the $18^{\text {th }}$ century to over 380 PPM in the $20^{\text {th }}$ century (United States Environmental Protection Agency, 2017; UNFCCC, 2015).

Climate change has far-reaching negative feedback effects on the environment and human beings. It destabilises the temperature equilibrium of the earth. It accounts for rising sea levels, high ocean temperatures, heavy rain, shrinking glaciers (Myclimate.org, 2020). Although the effects of climate change are not uniform, its direct consequences on human especially in developing countries include hunger, water crises, health risks, rising spreads of pathogens and pests, communal/ethnic conflicts, the decline in the gross domestic product (GDP) and forceful adaptations in areas of agriculture, energy, clothing, infrastructure, technology and housing. Despite these effects in Africa and every continent, the poorest of the poor are most at risk.

\section{Global attitude towards climate change}

As the social consequences of climate change intensify, global concern continues to gain momentum yearly. According to Stroke, Wike and Carl (2015), this concern varies from one country to another. In a survey by Pew Research Centre - spring (2018), most countries see climate change as a major threat to human society. Among these countries, Greece topped in the chat with (90\%), South Korea (86\%), France (83\%), Spain (81\%), Mexico (80\%), Japan (75\%), Argentina (73\%), Brazil (72\%), Germany, Kenya and Italy (71\%) respectively. The lowest being Israel (38\%), Nigeria (41\%), Poland (55\%), and Indonesia (56\%) (see Fig. 1). According to Fagan and Huang (2019), most countries express very high levels of concern for climate change since it has a top threat to the global economy. In every eight-in-ten countries surveyed, climate change is seen as a significant threat to humanity. Countries attitude towards climate change determine their commitment and policy options towards adaptation, mitigation and job creation especially in the green sector of the economy. 


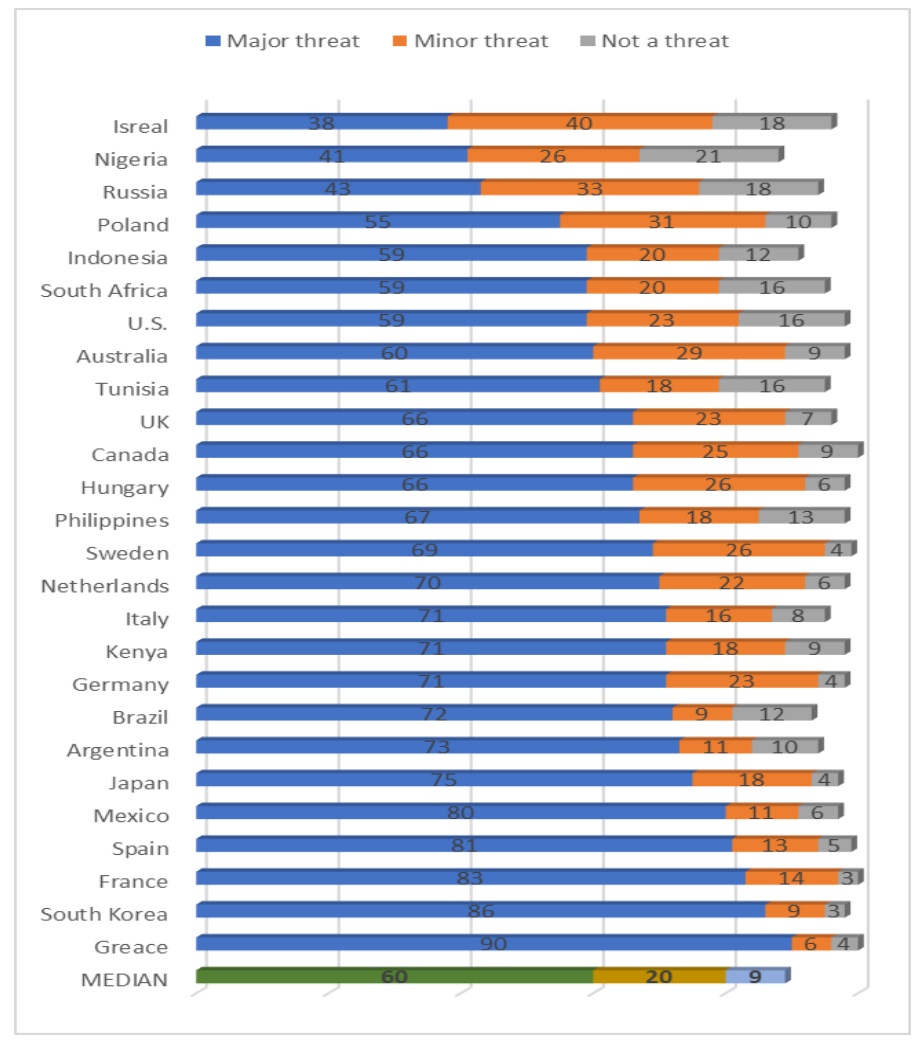

Fig. 1. View on climate change as a threat

Source: Pew Research Centre - Spring (2018)

Global attitudes survey by Pew Research Centre Spring (2015) on countries who saw climate change as a major threat and requires immediate and urgent actions by stakeholders revealed that Brazil (90\%) rank first in global concern for climate change; followed by Peru (79\%). Others are Argentina (78\%), Venezuela and Burkina Faso (76\%), Uganda (74\%), Japan (71\%), Chile and Mexico (68\%), Germany (66\%) and Italy $(65 \%)$. The list on the chart is Pakistan (16\%), followed by Indonesia (20\%), Palest. ter. (23\%), Turkey (24\%), Jordan (26\%) and Poland (28\%) (see Fig. 2).

\section{Climate change and global jobs}

Across nationals, climate change has a substantial impact on poverty reduction and job creation (Ahmed, 2018). According to International Labour Organisation (2019) report titles "Working on a warmer planet: The impact of heat stress and labour, productivity and decent work" revealed that global warming will lead to huge economic and job losses in 2030, with developing and underdeveloped nations being the most affected. It unveiled that in 2030, heatrelated stress at the workplace will lead to the loss of 80 million full-time jobs and $\$ 2.4$ trillion global economic losses. It shows that employees who work outdoors especially in the construction and agricultural sector will be most affected by increasing global warming. Sixty per cent $(60 \%)$ of global working hours lost occasioned by heat stress will come from agriculture and nineteen per cent (19\%) from the construction sector. The report further reveals that Southern Asia and West Africa will be among the hardest-hit regions. 


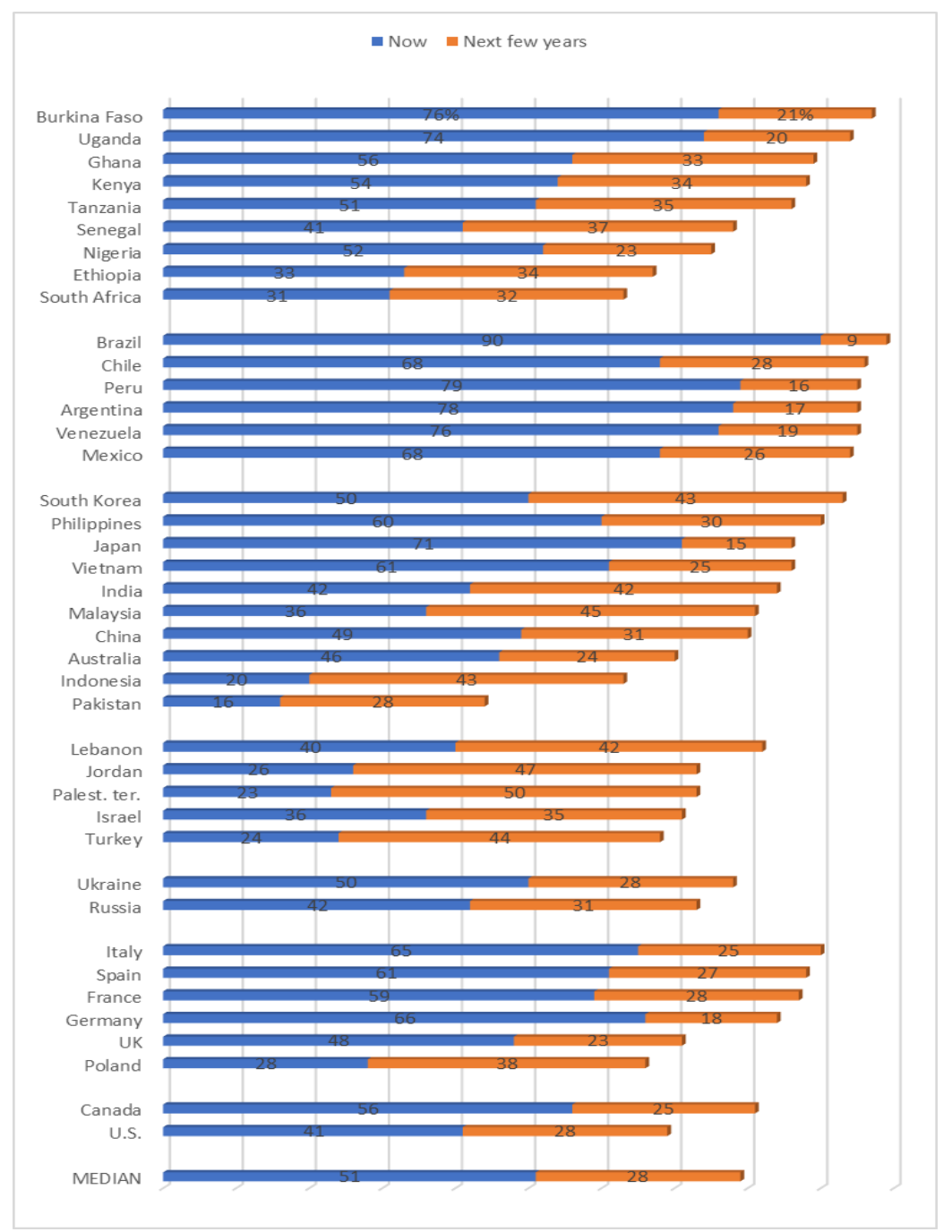

Fig. 2. Attitude of countries who view climate change as a threat and requires immediate attention

Source: Pew Research Centre - Spring (2015)

Continue global warming with an estimated rise of 1.5 Degree Celsius will dramatically alter the world of work by 2.2 per cent in 2030. Global warming causes "work-related heat stress", which damage workers' productivity globally (Wier, 2019). Global warming, therefore, constitutes a risk and negative impact on employment. As more countries transits from high to low-carbon economy, global employment is significantly altered. Again, as global efforts are geared towards mitigating climate change, employment opportunities world-wide dwindle. More so, as many countries adapt to climate change through innovative technology, greater jobs would be affected across continents. According to Evans (2015), a structural and paradigm shift from "high-carbon economy to a low-carbon economy" would result in gains and losses in employment opportunities.

\subsection{Adaptation to climate change and job creation}

As the world adapts to climate change, huge careers opportunities are created in the clean energy sector. This sector accounts for millions of what is popularly called "green jobs". According to United States Bureau of Labour Statistics, green jobs are "jobs in business that produce goods and provides services that benefit the environment or conserve natural resources or jobs in which workers' duties involve making their establishment's production 
processes more environmentally friendly or use fewer natural resources". Thus adaptation to climate change generates jobs in areas such as - (i) renewable energy, (ii) recycling and waste reduction, (iii) environmental compliance training, awareness and education, (iv) greenhouse gas and pollution reduction.

\section{a) Jobs in the renewable energy industry between 2017 and 2018}

Solar heating and cooling of the renewable energy unit in 2018 generated some 670,000 jobs in China, 41,000 employment in Brazil, 12,000 in the United States of America (USA), 20,7000 in India and 24,000 jobs in European Union (EU) comprising of 28 countries (see Fig. 3). Wind energy industry creates direct and indirect jobs in China to the tune of 510,000, in Brazil 34,000, USA 114,000, European Union 314,000 and India 58,000. Biofuel direct and indirect jobs in USA is 311,000, Brazil 832,000, EU 208,000, China 51,000, and India 35,000. In the same vein, Solar PV job opportunities in USA was 225,000, China 2,194,000, India 115,000, EU 96,000, and Brazil 15,600. Hydropower energy accounts for an estimated 308,000 direct and indirect jobs in China, 203,000 in Brazil, 347,000 in India, 66,500 jobs in USA and 74,000 in EU (International Renewable Energy Agency - IRENA, 2019). Thus, there is an estimated 11,000,000 direct and indirect employments in the renewable energy in 2018, China leading with 4,078,000 followed by EU countries 1,235,000 jobs (Environmental and Energy Study Institute - EESI, 2019).

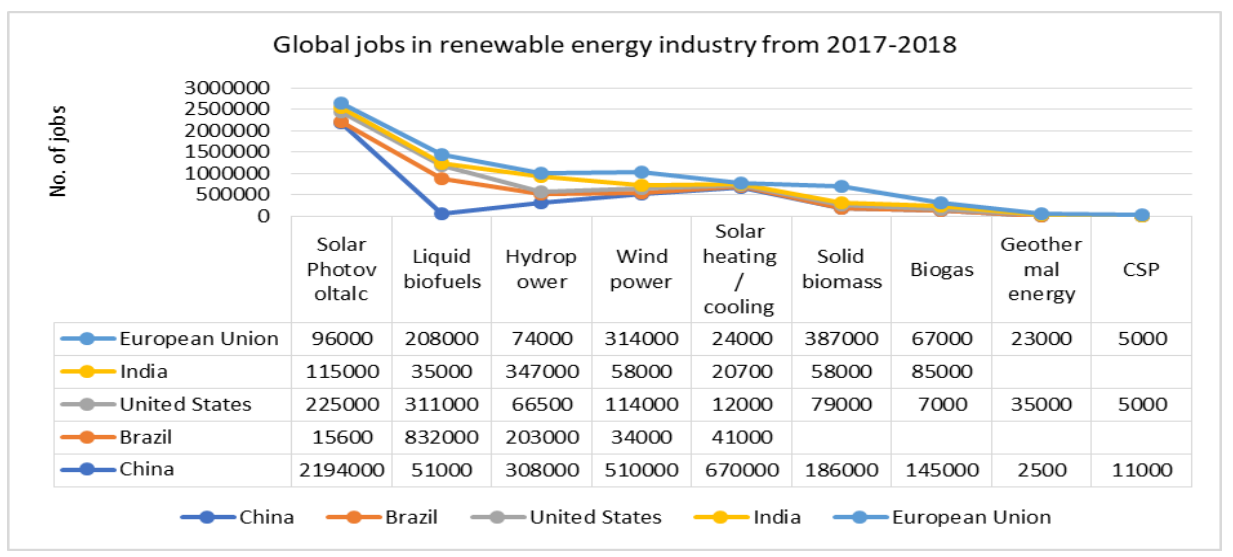

Fig. 3. Global jobs in the renewable energy industry from 2017-2018

Source: Environmental and Energy Study Institute - EESI (2019)

The green energy industry is also helping in small ways in solving the high unemployment rate in Africa. The "offgrid renewable energy" for example, solar panel energy is helping to create some direct and indirect jobs in Africa, thereby tackling the two biggest problems of unemployment and electricity in the continent. It impacts positively on jobs and power in Africa; for instance, it accounts for 10,000 jobs in Kenya and 4,000 in Nigeria in 2018. This trend is promising and still growing and may account for an estimated 17,000 jobs in Nigeria and 14,000 in Kenya by 2023 (Kazeem, 2019). This is crucial to economic development in Africa considering the rising unemployment rate, especially in Nigeria in the past four years. Kazeem (2019) posit that renewable energy jobs in Africa are projected to grow at an average of 65 per cent with Nigeria leading with over 100 per cent increase by 2023 . However, these projected benefits will remain a mirage if governments of Africa continue to complacent and show less commitment to the development of the clean energy sector.

\section{b) Employment in green manufacturing and transportation sector}

Like the renewable energy industry, one of the huge and fast-growing career fields is that of the green manufacturing and transportation industry. Manufacturers of products with low impact on the environment are creating huge job opportunities for thousands of people across the world. The span of their products defines the scope and frontier of the number of jobs the industry can provide. Thus, green products and its affiliate green jobs can be found in large commercial entities and homes. For example, green manufacturing industry employs chemists who produce 
environmental-friendly building materials, safer and better products including wears and home artefacts. The green manufacturing industry also provides employment for product managers who are in charge of the day-to-day coordination of the production of environmental-friendly items.

The exodus from automobile-based to mass public transportation is making green transportation inevitably a major employer of labour globally. The steady growth in this career field will create huge job opportunities for engineers who design mass public vehicles, drivers, and transportation managers. For instance, engineers are needed to design automobiles that use alternative fuel including hydrogen, natural gas, ethanol, propane, biodiesel and liquefied petroleum gas; as well as other power sources such as a battery, hybrid electrics and plug-in-hybrids (McClelland, n.d).

\section{c) Environmental compliance and educational training}

Career opportunities are widening in environmental compliance and educational training. This is because going green and sustaining the same requires more than technological innovations. It entails training and educating the masses, making laws and ensuring compliance. It includes the establishment of environmental protection agencies and developing new curriculum in schools to train manpower in these new fields. Individuals need to be trained on environmental protection, remediation, air quality protection, soil conservation, as well as research. A huge number of persons are already engaged in these areas and many more are needed globally. This trend is expanding as global warming becomes more evident even in many countries across the world, especially in developing countries.

\section{d) Waste recycling and management sector}

One of the largest growing sector across the world is that of waste recycling and management industry. The industry collects waste and recycles them for human use. Occupation in this industry includes waste treatment, solid waste management, wastewater recycling and management, etc. According to Zipay (n.d), job titles in this industry include - hazardous materials managers, refuse material collectors, recycling manager. It encompasses career jobs in the public, private and non-profit sectors. Recycling industry makes money out of waste and is creating a huge amount of wealth globally. Seabagers are seen in most streets of Africa, trying in a very limited way to make a living out of the waste collection.

It is worth noting that green jobs are on the rise, and are eradicating high unemployment. Green careers create new job opportunities 12 times faster than any sector of the economy. It accounts for over 20 per cent annual growth in the United States alone, this is because the cost of creating green jobs is less as compared to returns to investment. In most developed nations, one in every 80 jobs is in green energy segment of the economy (Homeselfe, 2018). Especially wind and solar industries are sprouting job opportunities in USA, Europe, and China. This may become a major frontier soldier if properly utilised in the eradication of high unemployment and poverty reduction especially in some part of Asia and Africa.

\subsection{Climate change adaptation and unemployment: Overview}

Although climate change accounts for a large number of green jobs, it is also a major cause of job lost globally. According to the ILO report (2019), global warming increases "work-related heat stress" and is largely responsible for an estimated 80 million job loss. It is projected that by the year 2030, over 2.1 per cent of working hours will be lost worldwide. Similarly, Poschen (2015) posits that global warming and loss of jobs are inextricably linked. This is because economic growth and job creation depend on natural resources. Climate change according to the International Institute of Labour Studies (IILS) will lead to a considerable increase in costs of production and reduction in outputs. This phenomenon will stimulate behavioural change among enterprises resulting in downsizing of workers to make a profit and ensure survival. This suggests that productivity levels will drop to the tune of 2.4 per cent as against 2010 and 7.2 per cent lower in 2050 (see Fig. 4) 


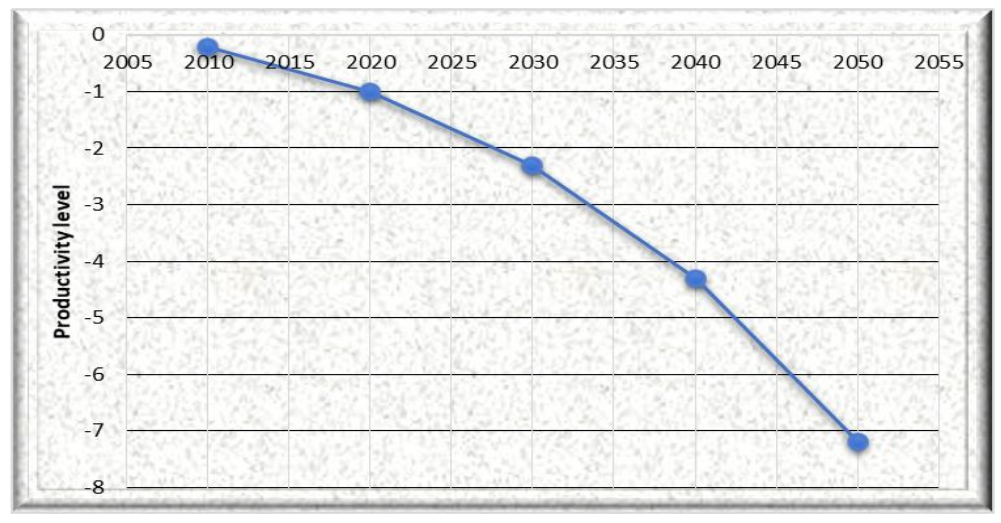

Fig. 4. Climate change and productivity loss (in percentage) from 2010-2015

Source: International Institute for Labour Studies (2019)

Climate change has huge negative impacts on jobs in the agricultural sector of society. Women who constitute the bulk of the 940 million workers in the sector will be most affected by 2030 and this may skyrocket by 2050 if global warming is not collectively and comprehensively addressed. According to Olsen (2009), agriculture employed over 1 billion persons and is the second-largest employer of labour next to services. An estimated 20 per cent of this labour is in sub-Saharan Africa while more than 70 per cent are in Asia. It is believed that, of the total labour force in the agricultural sector, 40 per cent are women. Extreme weather conditions such as droughts and floods occasioned by climate change have and will continue to impact negatively on the sector and its many employees.

Taylor (2019) argue that if greenhouse gases (GHGs) continue to increase, 19 per cent of workers in the construction industry will lose the jobs and this could be worst in Africa and Southeast Asia. The situation is no different in the transport, sport and tourism industry, where a good number of jobs are lost and more anticipated in the future. Extreme climate conditions could lead to unemployment and massive economic costs with a worsening scenario in poorest countries. The tourism industry, for instance, is "human-resource intensive", every one job creates an estimated two indirect jobs in the wider economy (Olsen, 2009). It accounts for some 8 per cent (that is 230 million) of the entire global labour force, with women constituting over 69 per cent of the workforce in the industry (Bolwell \& Weinz, 2008). This industry is significantly affected by climate change that results in high sea levels, that submerged islands and coastal areas, cause severe coastal erosions, droughts, and death of wildlife. Global warming also accounts for the intrusion of saltwater into island making them uninhabitable in the nearest future. Again, adaptation to climate change informs the transition of "old jobs" to "green/new jobs". This results in the transformation and disappearance of old jobs. The impact is that many old jobs will be lost rendering a large number of persons unemployed worldwide.

\section{Climate change and unemployment in Africa}

Africa is the most populous continent next to Asia. It has a landmass of 11.7 billion square miles and it covers about 6 per cent of the earth's total surface area. With a population of 1.3 billion people as in 2018, the continent accounts for 16 per cent of the worlds' population. Despite the huge resource of Africa, the continent remains one of the poorest in the world with the majority of its population suffering from poverty, malnutrition, poor health, illiteracy, and unemployment (UN Department of Economic and Social Affairs, 2019). Despite Africa's low contribution to greenhouse gas emissions, the continent remains the most vulnerable to climate change (Africa Development Bank, 2020). The connection between climate change and unemployment in Africa especially in the agricultural sector is evidential and undisputable. The drying of lakes, droughts, and desertification in some parts of the North, East, Central and West Africa is directly linked to climate change. Persuasive and compelling evidence shows that Africa is currently facing huge environmental challenges emanating from climate change and this is severely impacting negative consequences in the agricultural segment of its economy. According to Freeman (2017), a large proportion of Africa farmers are reliant on "rain-fed" farming; this makes farmers in the continent more vulnerable to global 
warming. With the continuous climate change, food insecurity and lost of agriculture-based has become the two major social consequences of this dynamic jobs in South Africa, West Africa, the Horn, Central Africa, and the Sahel region.

According to the World Bank (2019), unemployment, especially among youths, remains a major social problem in Africa. Unemployment in the continent as at 2019 ranges from 0.3 per cent in Niger to 33.4 per cent in Namibia (see Fig. 5).

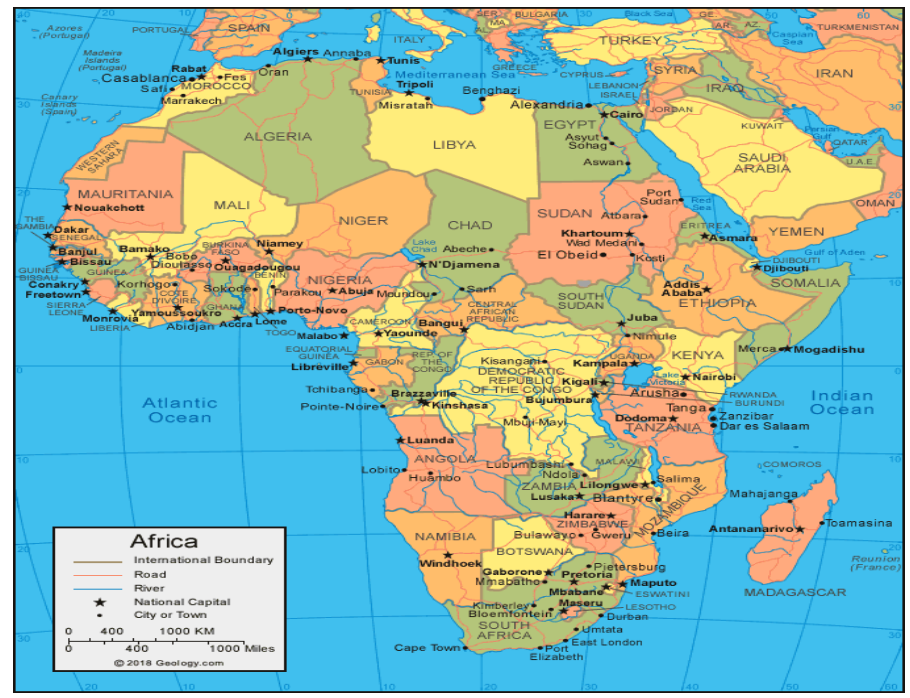

Fig. 5. Map of Africa

Source: Geology.com @ 2008

International Labour Organisation - ILO (2016) posit that with the high levels of unemployment and the rising index of vulnerable employment, creating and securing jobs remains an uphill task for governments across Africa. Although poor job quality remains a major issue globally, the situation is endemic in Africa where over 70 per cent of the workforce are in vulnerable employment against the acceptable global average of 46.3 per cent. The informal sector in the continent contributes about $40-70$ per cent of the employment in the continent with most of these SMEs domicile in the agricultural sector of the economy.

The employment trend of Africa as portrayed by ILO above is not without negative socio-economic impacts. According to the Unicef report (n.d), the history of social conflicts in Africa is significantly associated with unemployment. Unemployment is linked to the emergence of militia and terrorist groups across the continent including Boko-Haram in northern Nigeria, Al-Shabaab in the Horn of Africa, Niger Delta Militant in South-South Nigeria, etc. While these problems abound, concrete evidence shows that the unemployment situation and its associate consequence can be significantly reduced through policy options that create green jobs and at the same time mitigate climate change.

\subsection{Climate change and unemployment in South Africa (SA)}

The South Africa region includes Namibia, Swaziland, Lesotho, Botswana, and South Africa. Climate change is escalating the current unemployment rate in the SA region which is now at 29.1 per cent, the highest in the past 16 years (Eyewithness News, 2020). This situation is worsening with the looming of the fourth economic revolution which is characterised by green technology and advanced mechanisation of production processes. A large number of unskilled and semi-skilled labour is more likely to lose their jobs. Some skilled labour is not spared from this economic reality as many are increasingly becoming redundant (Mathunjwa, 2017). Similarly, Wright, Gerland, Norval, and Vogel (2014) posit that climate change has further complicated the challenges of unemployment, poverty, human health, food, and water insecurity in the SA region. 
Agriculture is the main source of livelihood and a major provider of employment in SA. It accounts for 50 per cent of jobs and contributes about 30 per cent to SA's gross domestic product (GDP). With the increasing average minimum monthly temperature of 138 Degree Celsius and dwindling average rainfall of $450 \mathrm{~mm}$ per year, agricultural activities in SA is directly affected (World Bank, 2010). The sector is most affected because it is highly dependent on precipitation, humidity, and temperature. Climate change impacts negatively on crop production and animal farms, thereby obstructing human efforts to addressing poverty, food insecurity, unemployment, and other developmental stresses (Maponya \& Mpandeli, 2012). The fear is that, if this trend continues, SA will exceed the limits of its adaptation strategy looming to the entire region into economic disaster. At present, several workers in the agriculture sector are already losing their livelihood because of declining yields and many more will join in the next 5 to 10 years.

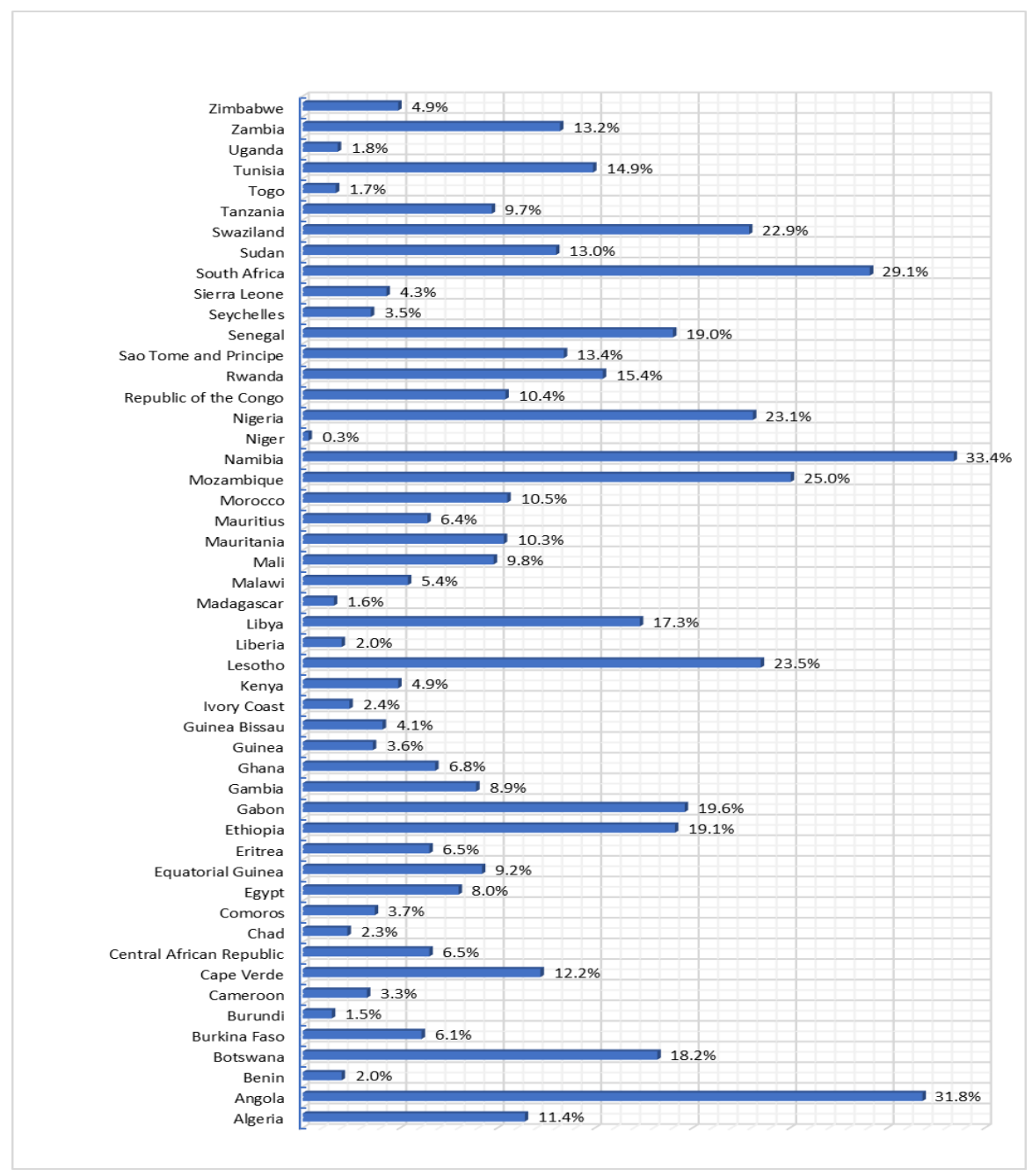

Fig. 6. The unemployment rate in Africa (Dec. 2019)

Source: Trading economics (2020).

According to the United Nations Economic Commission for Africa - ACPC report on "Economic growth development and climate change in Africa", the cost of climate change in Africa including SA is high. The report also demonstrates substantial development risks and a significant drop in GDP by 2050 occasioned by climate change. It shows that climate change poses additional threats and constraints to development. However, mitigating climate 
change will benefit and co-benefits Africa including SA in job creation and macroeconomic stability. The cumulating effect of climate change on employment and livelihood shows that more than 2.7 million households were affected by droughts since the 1980s and this number is increasing daily. Fagan (2020) posits that climate change in Zimbabwe is causing extreme poverty to increase at the rate of 5 per cent since 2019, leaving more than 5.7 per cent in dare need of food. Drought also leads to power interruptions which impact negatively on mining and crop storage as well as jobs in the affected sectors.

\subsection{Climate change and unemployment in West Africa}

Like any other part of Africa, climate change is obstructing socio-economic development in West Africa. The region comprises of 16 countries including Benin, Burkina Faso, Ghana, Guinea-Bissau, Gambia, Guinea, Liberia, Ivory Coast, Niger, Mali, Mauritania, Senegal, Nigeria, Sierra Leone, and Togo. These countries occupy an area of approximately 2,370,667 miles squared; about a fifth of the entire Africa continent (World Atlas, n.d). As in 2018, West Africa has an estimated population of 381 million people (UN Development of Economic and Social Affairs, Population Division, 2019). More than 70 per cent of its labour engage in rain-fed agriculture. Climate change according to the UN Economic Commission for Africa could lead to a loss of 15 per cent of GDP of West Africa by 2050. The implication is that a large number of workers in the agricultural sector will be without jobs and livelihood, placing the sub-region in high economic risk. According to the World Meteorological Organisation (2017), climate change is a major threat to food security in West Africa. This situation is worst because of the widespread poverty in the region and its marginal adaptation ability.

The decrease in rainfall in parts of West Africa is also causing weather-related disasters such as droughts and drops in water levels. Economic activities that revolve around water levels including dams, irrigation and transportation are adversely affected. For instance, Ghana reliant on hydro-electric power from Akosombo Dam is affected by the changing water levels in River Volta. Similarly, Mali depends on River Niger for agriculture activities, transportation and drinking water. The devastating climatic conditions are reducing these human activities rendering many jobless and without a source of sustenance. Drought has also led to a serious reduction in livestock production and loss of livelihood. The changing climate is impacting on human health by increasing the spread of tropical disease such as malaria, dengue fever, etc. On the correlates between the trend of climate change and employment, UNDP posits that 50 to 90 per cent of the West Africa population who engage in agriculture will be adversely affected. This is because, change in the intensity, seasonality and amount of precipitation will compromise agricultural output resulting in loss of income and laying-off of workers or job cut.

\subsection{The drying of Lake Chad and unemployment}

The hydrological shrinking of the Lake Chad remains a serious environmental and social problem to Nigeria, Cameroon, Niger, and the Republic of Chad. This is because the diminution of the Lake shape has negatively impacted on the livelihood and security of the lake dwellers. Studies of Kafumbata, Jamu and Chiotha (2014), Okpara, Stringer and Doughill (2016), Zieba et al. (2017) has shown similar links. Chad Lakeshore dwellers are losing a range of job opportunities as a result of severe drops in water levels. Specifically, it undermines livelihood in the agricultural sector especially in crop farming, fishing, and agro-processing. Since Lake Chad is located and share borders with Cameroon, Chad, Niger and Nigeria, its water-levels fluctuation is impacting immensely on the socioeconomic lives of the lake dwellers and its immediate environment.

Lake Chad before its dwindling state, was once one of the largest "freshwater bodies" in Africa, providing a livelihood for some 40 million people. Its fast varnishing state supports the emergence of violence and militia organisations in the region including Boko-Haram. According to Usigbe (2020), the drying of Lake Chad gives rise to conflicts, displacement of people, food insecurity, and joblessness. The water level of Lake Chad diminished by over 90 per cent, as a result of climate change and poor management, this leads to the loss of some 10 million direct and indirect jobs. An estimated 10.7 million person in the Lake Chad region need urgent humanitarian assistance and many more are struggling to survive. Migration of people seeking for survival is a "new normal" in the region, while the conflict between farmers and herders have become a common phenomenon because of the drying Lake Chad. 


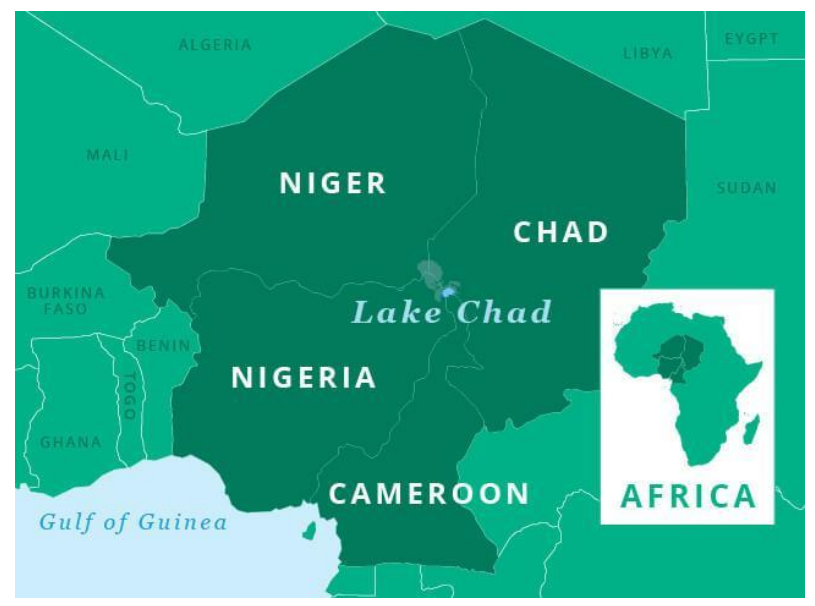

Fig. 7. Map of Lake Chad and bordering countries

Source: Google image (n.d)

Campbell (2018) argue that Lake Chad shrunk from 25,000sq.kms to 2,000sq.km in the past 50 years and it is difficult to quantify the harm it unleashed on livelihood. It shrinks grazing lands and fishing grounds setting up a new economy for the lakeshore dwellers. Fish processing facilities are now turned into a military base for young jihadists. Again, the extinct of the swimming cow, a rare species of cattle found only in the Chad Basin is becoming very obvious and this is rendering more herders jobless. Herders are now drifting southwards for pasture and water because of the shrinking lake orchestrated by climate change.

\subsection{Drought and unemployment in East Africa}

East Africa (EA) is well known for her pastoral activities which constitute a significant source of employment in the region (World Bank, 2014). The increasing drought associated with climate change poses a major threat to pastoral communities in Kenya, Ethiopia, and Uganda (Schilling, et al., (2015). The exodus of pastoral groups and their quest to gain control over water points results in violent conflicts, loss of lives, jobs and property. According to Haile, Tang, Sun, Huang, Zhang, and Liu (2019), drought in EA has extensive impacts on agriculture, human beings and the environment. Consequently, in most recent years, EA has been a primary focus of many drought studies.

Drought in EA is a major challenge in ensuring food security. Its impact on crop yields is largely negative and overwhelming. It is reported that more than 35 per cent of valuable crops such as millet, rice, maize, soybean, sorghum, potato, cassava, tea, and coffee of the present yield will decline in the nearest future leaving a large number of farmers without a livelihood. The impact of drought on livelihood is even more grievous, considering the fact that EA countries including - Ethiopia, Uganda, Kenya, Tanzania, Zambia, Malawi, and Mozambique, are of agriculturebased, that is, dominated by small households who accounts for 90 per cent agriculture products. Agriculture contributes more than 21-42 per cent of the gross domestic products (GDP) of these countries (Adhikari, Nejadhashemi \& Woznicki, 2015).

For instance, in some parts of Kenya, severe drought curtails crop production, skyrocketing prices of food items and poses serious strains to economic growth. It accounts for the killing of herds and also blamed for high inflation rates of about 11.48 per cent, with food and non-alcoholic drinks topping the chat with over 21 per cent inflation rate in 2017. With the surging prices, the agricultural sector is also facing a feedback effect especially in an exported commodity such as tea. Given the unemployment rate in Kenya to be 39 per cent (Dahir, 2017), further downdrift in agricultural activities as a result of drought will leave many households jobless and some more in a worsening economic condition. According to Food and Agriculture Organisation of the United Nations (2018), if drought and other challenges facing agriculture is properly addressed, the sector has promising potentials in solving the increasing youth unemployment, distress migration, food insecurity, and rural poverty in EA countries. 


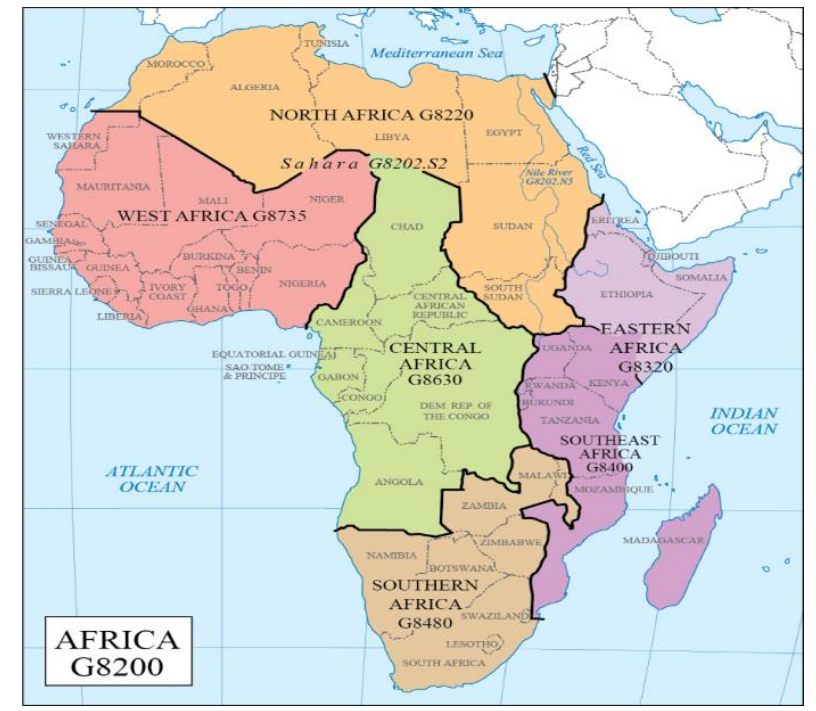

Fig. 8. Map of Africa showing the 5 regions

Source: Pinterest.com (2020)

\subsection{Climate change and unemployment in North Africa}

North Africa consists of 7 countries including Algeria, Libya, Egypt, Morocco, Sudan, Tunisia, and Western Sahara. Apart from Libya and Algeria whose economy is transformed by the discovery of gas and oil, others depend significantly on agriculture and tourism industry. Activities in these industries are undermined by the trend of climate change in the region. The rising temperature shortens planting seasons, reduce crop yields, and decrease land mass suitable for agriculture. It is expected that a further decrease in annual rainfall will exacerbate the situation and probably set the wheels of development backwards in the $21^{\text {st }}$ century. According to Olaimy (2013) and Radhouane (2013), climate change in North Africa threatens lives, livelihoods and impedes socio-economic development, and mitigating climate change will divert vital resources from programmes that address unemployment, poverty, and poor living conditions.

Unemployment is considered as one major socio-economic problem facing the Northern Africa region aggravated by extreme weather conditions. This is because, climate change trends informs flooding, droughts, water scarcity and salinization, which adversely impact on agriculture, forcing a large number of farmers off their land and off-job. Climate's stress exacerbates already substantial rural-urban migration in northern Africa forcing high unemployment, deteriorating living conditions and civil conflicts. It is also estimated that by 2030 , three-quarters of people in the region will have insufficient access to freshwater (National Intelligence Council - NIC, 2009).

The tourism industry is also a major source of income and employer of labour in North Africa. This sector of the economy is threatened by the increasing water scarcity, temperatures, and rise in sea levels. According to NIC (2009) report, climate change is likely to have a negative impact on the tourism sector and consequently on the economy of the region at large, and this is expected to increase in the $21^{\text {st }}$ century. The likely effect is that a significant number of workers will lose their jobs as companies in the tourism sector tries to adapt to climate change. Many more firms in the hospitality and subsidiaries may fold-up leading to huge loss of livelihood. Again, the economies of Algeria, Egypt, and Libya dependent on hydrocarbon industry. Shift in oil and gas consumption by most countries in Europe and America because of climate change mitigation programmes is adversely affecting the economy of Algeria, Libya and Egypt; and these are not without negative consequences on jobs. The accumulated impacts of climate change in North Africa, according to the Global Ideas report of 2015 could trigger another round of regional revolution after the order of the Arab spring that battered Northern Africa in 2011. 


\section{Urgent policy options and actions for Africa}

Given the huge cost of climate change on the continent of Africa especially on livelihood and jobs, there is, therefore, need for urgent policy direction and concrete actions. This suggests that Africa countries must go beyond mere lip service, conferences, summits, and declarations, to the making of pragmatic and obtainable policy and concretely implement same. The continent must begin to look at possible and realistic means of solving the unemployment problem that is been exacerbated by climate change and sustaining such efforts. Comprehensive efforts must be geared towards reviving the agricultural sector which employs 90 per cent of Africa's labour force but is currently vulnerable to climate change. Policy options must include creating green jobs, especially in the solar sector, wind, hydro-power, and bio-fuel sectors. The following are therefore suggested in this paper as policy options and actions for the continent of Africa:

\subsection{Reviving of Lake Chad for job creation and climate change mitigation}

Lake Chad provides direct and indirect jobs as well as a means of livelihood to some 30 - 40 million people in Nigeria, Chad, Cameroon, and Niger. These jobs as earlier discussed in this paper are threatened by climate change. The lake may disappear in the nearest two decades if concrete actions are not taken. The first step, therefore, is to seek measures to restore the lake through scientific and technological innovation that allows for the transfer and storage of water.

The immediate border countries to Lake Chad and other remote neighbours such as Libya, Central Africa Republic, Sudan, and Algeria must galvanise resources through annual and special intervention funds to finance the project. Supports should be sought from Africa Development Bank, United Nations, World Bank, and other donor agencies. Political will and adequate commitment are required from all stakeholders.

Abuja declaration on "Saving Lake Chad" should vigorously be pursued and implemented by stakeholders. It involves transferring of water from Congo-Oubangui-Sangha Basin to Lake Chad Basin. It includes diversion of water from the Congo River covering about $1,300 \mathrm{~km}$ to Chari River that feeds Lake Chad. This project was first proposed in the 1960s but lack concrete actions from stakeholders. The modified version should, therefore, include the construction of retention dams and the generation of hydroelectricity. This will not only support "old jobs" at the lake but also create sustainable new employment opportunities in water transportation, tourism, fishing, crop farming, livestock and hydropower industry. It will curtail poverty, herders-farmers conflicts, mitigate drought and control desertification. Again, stakeholders should set timeframe for completing the project.

\subsection{Reviving of other water resources and agricultural activities}

River Nile, Niger, Congo, and Benue Rivers are also water sources that support agricultural activities in Africa that needs urgent policy attention. If agriculture must continue to be a major employer of labour, these water sources should be revived without delay by stakeholders. Policies across countries that benefit from these water sources should be directed towards the promotion of integrated water management. Funds should be committed by stakeholders for the construction of facilities that collects, store and supply water to stabilise watershed and support irrigation farming. Capacity should be built to develop technologies that support drip irrigation, this includes the promotion of small-scale irrigation programmes among stakeholders.

Agricultural policies that promote and supports capacities in the production of drought resistance crops should be introduced in East, North, Central and South Africa regions. Efforts should be channelled to the improvement of alerts systems that forecast rainfall, pest, disease, and food security in these regions. More so, livestock and pastoral policies that improve rangeland management and general land use should be supported. The policy should include the introduction of schemes that promotes the establishment of livestock feed banks. Improved species of crops should be introduced in grazing lands to reduce desertification.

\subsection{Developing biofuel industry for job creation}

Although policy attempts have been made to develop the biofuel industry in Africa, however, many of such efforts have been abandoned and in some cases given less attention. Given huge biodiversity of the continent and global 
focus in the development of bioenergy, as well as the opportunities biofuel industry offers, concrete policy option in this area is vital. The industry should be developed and used as instrument par-excellence for effective rural transformation and job creation. Since more than 90 per cent of rural folks in Africa engage in agriculture as means of livelihood, the policy should be channelled towards utilising this great potential in rural areas while at the same time protecting the natural environment and mitigating climate change.

Funds should be committed to supporting small and medium scale participation in biofuel production. Farmers should not only be engaged at primary levels, but be trained at the processing levels. This will help reduce rural-urban labour drift that characterised most societies in Africa. Again, the policy should be developed to support the diversification of the Africa economy, which at present is "mono-economy". Engineers and craftsmen should be trained to fit into innovations in the biofuel industry thereby creating substantial jobs for university graduates and semi-skilled labour.

The biofuel industry if properly developed will generate millions of dollars for both government and the private sector. For instance, Nigeria alone in 2020 as projected by Agba, et al (2010) needs 2.0 billion litres of ethanol and 900 million litres of biodiesel. Sales from these products will boost GDP and foreign earning of the country. It entails that, this policy option should encourage the cultivation of crops such as maize, groundnut, rice, millet, yam, cassava, and potato, including tree crops like palm oil in large quantities for biofuel production without compromising food security of the continent. Government of respective countries should embark on awareness campaigns and training of people to handle outlets and the downstream sectors of the biofuel industry.

\subsection{Developing the solar industry for job creation}

Africa is endowed with abundant untapped solar energy that is capable of generating large employment opportunities for present and future generations. The continent is the sunniest in the world receiving more than 2,000 kilowatthours of solar energy per square meter annually. Despite the huge solar potentials, investment in the sector is still very low. As various legislations continue to thrive towards reducing carbon footprint, the continent of Africa has no excuse but to grasp this opportunity and invest in the solar energy sector. Governments in Africa should encourage private and public sector participation in the solar industry through legislation, financial commitment, and tax waiver policy. Tax holidays should be given to potential investors for at least 2 to 4 years. Large scale manpower training should be carried out across the continent by different governments. Partnership with already developed solar companies in Germany, Russia, China and the United States of America should be encouraged among governments of Africa. Apart from solving the electricity problem of the continent and mitigating climate change, the solar energy industry has the capacity of creating millions of jobs for Africans in the next five years. It will help build capacity in green powered technology in Africa.

\subsection{Developing wind energy industry for job creation}

The most under-utilised energy in Africa is wind. Even in Africa's media, Tony Tiyou, Director of Renewables in Africa posit that "wind energy is still relatively unknown, at best only mentioned in generic terms". The implication is that many governments and investors in Africa are not even aware of the huge wealth and employment potentials embedded in wind energy. While hydropower is historically the largest clean energy source for electricity supply in Africa, wind energy utilisation is lagging. The wind energy potentials that requires urgent policy support in different regions of Africa is depicted in Fig. 9. Whether at 30 or 40 per cent capacity factor (CF), the wind energy if properly utilised would supply 51 times the entire electricity demand of Africa.

Governments across the continent must first, establish a clear regulatory and strategic framework. The policy should include manpower training in technology innovations in wind energy utilisation and economy. Transmission and distribution systems should be taken into consideration to ensure supplies reach the consumer at a low cost. Wind energy industrial policy should include the establishment of departments and units in tertiary schools for sustainable manpower training and development. Existing mechanical and electrical engineering departments in Africa universities and polytechnics should be equipped to cater to the technological needs of the wind energy industry. Again, governments in Africa should encourage private sector participation through adequate financial and technical supports. The benefits of this policy drive, includes - job creation, climate change mitigation, adequate electricity supply, wealth creation, and increase in GDP of Africa. 


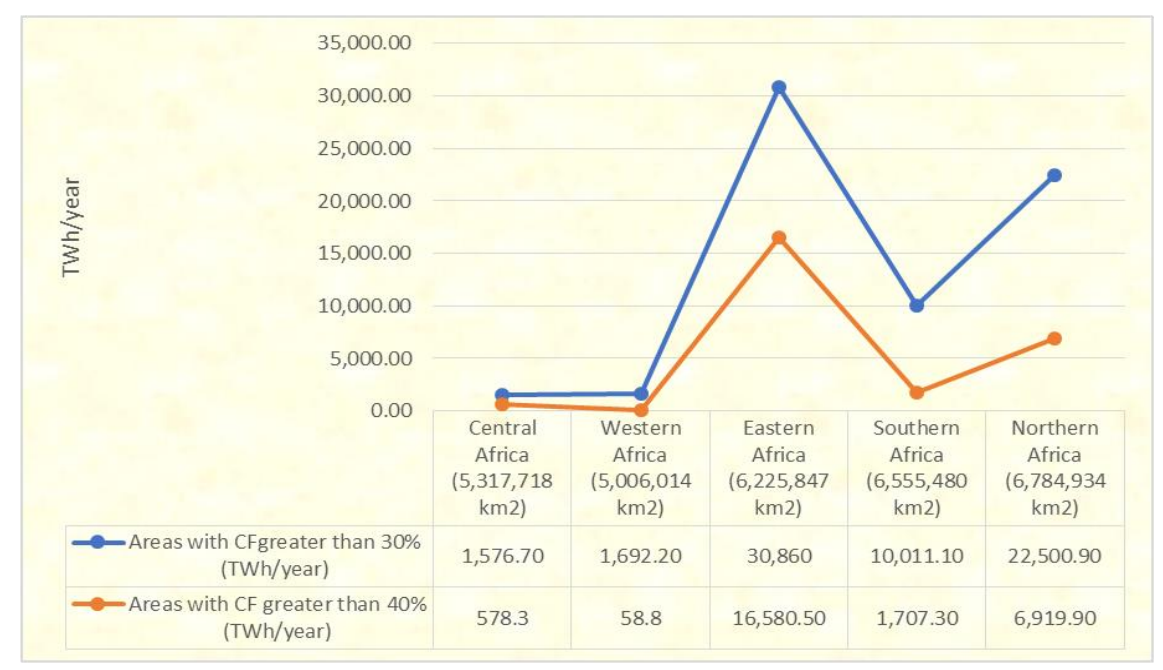

$\mathrm{CF}=$ Capacity Factor

$\mathrm{TWh}=$ Terawatt hours

Fig. 9. Wind energy potential in different regions of Africa

Source: Africa's Power Journal Report (2018).

\section{Conclusion}

Climate change remains a significant challenge to both developed and developing nations, with countries of Africa and South Asia being the most afflicted. Climate change alters human activities and impacts negatively on livelihood and jobs. Adaptation to climate change creates new job opportunities in the green energy sector and at the same time threatens old jobs. While many developed nations are taking the advantage climate change adaptation offers to create clean jobs that of Africa which of course are the most vulnerable are complacent and less concerned. This attitude accounts for the high rate of unemployment, poverty, low yield of crops, and death of livestock, health problems, and social conflicts. As this situation continues to grow worst without tangible efforts from governments of Africa, this paper made some policy recommendations that will help the continent adapt favourably to climate change and at the same time address the rising levels of unemployment. The paper suggested that government across Africa should make policies that support public and private sectors investment in solar, wind, and biofuel industries to create green jobs and mitigate the rising rate of unemployment and curtail social upheavals associated with it. We recommend that lakes and other water sources that support agriculture in Africa should be revived since 90 per cent of the continent's workforce can be accommodated in the agricultural sector. The paper holds the view that such policy drive will help strengthen the hydro-power industry, solve the electricity problem of Africa, boost agriculture and create green jobs for the unemployed.

\section{Conflict of interest}

The authors declare no conflict of interest.

\section{References}

Adhikari, U., Nejadhashemi, P. A. \& Woznicki (2015). Climate change and eastern Africa: A review of impact on major crops. Food and Energy Security, 4(2), 110-132.

Africa's Power Journal Report (2018). The state of wind energy in Africa. Online available at https://www.esiafrica.com/top-stories/the-state-of-wind-energy-in-africa/. Retrieved May 12, 2020 
African Development Bank Group (2020). Climate change in Africa. Online available at http://afdb.org/en/cop25/climate-change-africa. Retrieved May 7, 2020.

Agba, A. M. O., Ushie, M. E., Abam, F. I., Agba, M. S. \& Okoro, J. (2010). Developing the biofuel industry for effective rural transformation in Nigeria. European Journal of Scientific Research, 40(3), 441-449.

Ahmed, S. (2018). Green jobs in the era of changing climate. Online available at https://sustainabledevelopment.un.org/content/documents/5794greenjobs.pdf. Retrieved April 13, 2020.

Australian Academy of Science (2020). What is climate change? Online available at https://www.science.org.au/learning/general-audience/science-climate-change/1-what-is-climate-change. Retrieved April 13, 2020

Bolwell, D. \& Weinz, W. (2008). Reducing poverty through tourism. Geneva: International Labour Office

Dahir, A. L. (2017). A biting drought and rising inflation are hampering Kenya's economic growth. Online available at https://qz.com/africa/980255/drought-in-kenya-is-causing-inflation-to-soar-and-could-undermine-theeconomy/. Retrieved May 4, 2020.

Environmental and Energy Study Institute - EESI (2019). Fact sheet - Jobs in renewable energy, energy efficiency, and resilience. Online available at https://www.eesi.org/papers/view/fact-sheet-jobs-in-renewable-energy. Retrieved April 14, 2020.

Evans, J. (2015). Workforce and employment. Online available at https://www.weforum.org/agenda/2015/12/whatimpact-is-climate-having-on-jobs/. Retrieved April 13, 2020.

Eyewitness News (2020). Unemployment, climate change adding to SA's economic risks, say IRM. Online available at https://ewn.co.za/2020/02/19/unemployment-climate-adding-to-sa-s-economic-risks-says-irm. Retrieved May 5, 2020.

Fagan, L. (2020). Africa's economic outlook reveals both potential, uneven prospects. Africa Times, 4 Feb. 2020 Edition. Online available at http://africatimes.com/202/02/04/africas-economic-outlook-reveals-bothpotential-uneven-prospects/. Retrieved May 6, 2020.

Fagan, M. \& Huang, C. (2019). A look at how people around the world view climate change. Fact Tank: News in the Numbers. Online available at; https://www.pewresearch.org/fact-tank/2019/04/18/a-look-at-how-peoplearound-the-world-view-climate-change/ Retrieved May 11, 2020

Food and Agriculture Organisation of the United Nations (2018). Agriculture has the potential to address East Africa's youth unemployment challenge. EA: FAO Regional Office for Africa.

Freeman, L. (2017). Environmental change, migration and conflict in Africa: A critical examination of the interconnections. Journal of Environment and Development, 0(0), 1-24.

Geology.com (c) (2008). Africa Map and Satellite Image. Online available at https://geology.com/world/africasatellite-image.shtml. Retrieved May 12, 2020

Global Ideas (2015). Climate change will cause the next revolution in North Africa. Online available at http://dw.com/em/climate-change--north-Africa/a-18620521. Retrieved May 7, 2020.

Google image (n.d). Lake-Chad-Map-FULL-(1a) (1) - Intervention. Online available at https://www.google.com/imgres?... Retrieved May 12, 2020.

Haile, G. G., Tang, Q., Sun, S., Huang, Z., Zhang, X. \& Liu, X. (2019). Droughts in East Africa: Causes, impacts and resilience. Earth-Science Reviews, 193: 146-166

Homeselfe (2018). How does green technology create jobs? Online available at https://www.homeselfe.come/howgreen-technology-creates-jobs/. Retrieved April 6, 2020. 
ILO (2019). Working on a warmer planet: The impact of heat stress on labour productivity and decent work. Online available at https://www.voanews.com>ilo... Retrieved April 16, 2020.

International Institute for Labour Studies (2009). Global economic linkages. A model of employment and income dynamics in open economies. Discussion paper 198 of IILS, presented 07 October 2009.

International Labour Organisation - ILO (2016). Facing the growing unemployment challenges in Africa. Online available at http://ilo.org/Africa/media-centre/pr/WCMS_444474/lang--en/index.htm. Retrieved May 11, 2020.

International Renewable Energy Agency - IRENA (2019). Renewable capacity statistics 2019. Abu Dhabi: IRENA.

Jackson, S. T. (2018). Climate change. Britannica Online Encyclopaedia. Available at: https://www.britinnica.com/science/climate-change. Retrieved April 13, 2020

Kafumbata, D., Jamu, D. \& Chiotha, S. (2014). Riparian ecosystem resilience and livelihood strategies under test: Lessons from Lake Chilwa in Malawi and other lakes in Africa. Philosophical Transaction of the Royal Society B., 369: 1-12.

Kazeem, Y. (2019). Off-grid renewable energy is helping tackle two of Africa's biggest problems. Online available at https://qz.com/africa/1667158/renewable-energy-jobs-rise-fact-in-nigeria-india-kenya/. Retrieved April 14, 2020.

Maponya, P. \& Mpandeli, S. (2012). Climate change and agriculture production in South Africa: Impacts and adaptation options. Journal of Agricultural Science, 4(10), 48-60.

Mathunjwa, J. (2017). A just transition from climate change and unemployment. The Bullet, November 14, 2017 edition. Online available at https://socialistproject.ca./2017/11/b1512/. Retrieved May 5, 2020.

McClelland, C. L. (n.d). Green jobs in transportation. Online available at https://www.dummies.come/career/careerplanning/choosing-a-career/green-jobs-in-transportation/8. Retrieved April 22, 2020.

Myclimate.org (2020). What are the effects of climate change? Online available at https://www.myclimate.org/information/faq/faq-detail/detai/News/what-are-the-effects-of-climate-change/. Retrieved April 13, 2020.

National Intelligence Council - NIC (2009). North Africa - The impact of climate change to 2030: Geopolitical implications. Conference report of December 2009. Online available at http://dni.gov//files/documents/2009\%20conference\%20Report_North20Africa_the\%20impact\%20climate\% 20change... Retrieved May 7, 2020.

Okpara, U. T., Stringer, L. C. \& Dougill, A. J. (2016). Lake drying and livelihood dynamics in Lake Chad: Unravelling the mechanisms, context and responses. Ambio, 45(7), 781-795.

Oloimy, T. A. (2013). Climate change impacts in North Africa. Online available at http://3blassociations.com/climate-change-impacts-in-north-africa. Retrieved May 7, 2020.

Olsen, L. (2009). The employment effects of climate change and climate change responses: A role for international labour standard. Geneva: ILO.

Pew Research Centre - Spring (2015). Global Attitude Survey. Online available at https://www.pewresearch.org/facttank/2019/04/18. Retrieved April 14, 2020.

Pew Research Centre - Spring (2018). Global Attitude Survey. Online available at https://www.pewresearch.org/facttank/2019/04/18/a-look-at-how-... Retrieved April 15, 2020.

Pinterest.com (2020). C G Schedule Map 33: Africa Regions | WAML Information Bulletin. Online available at https://www.pinterest.com/pin/834432637196713367/ Retrieved May 12, 2020. 
Poschen, P. (2015). Lost job and the collateral damage of climate change. Online available at https://www.greenbiz.com/article/lost-jobs-and-economic-damage-climate-change. Retrieved April 28, 2020.

Radhouane, L. (2013). Climate change impacts on North African countries and on some Tunisian economic sectors. Journal of Agriculture and Environment for International Development, 107(1), 101-113.

Schilling, J., Locham, R., Weinzierl, T., Vivekananda, J. \& Scheffran, J. (2015). The nexus of oil, conflict, and climate change vulnerability of pastoral communities in Northwest Kenya. Earth System Dynamics Discussions, 6: 1163-1200.

Strokes, B., Wike, R. \& Carle, J. (2015). Global concern about climate change: Broad support for limiting emissions. Online available at https://www.pewresearch.org/global/2015/11/05/1-concern-about-climate-change-andits-consequences. Retrieved April 14, 2020.

Taylor, L. (2019). $80 \mathrm{~m}$ jobs could be lost by 2030 due to climate change: UN. Online available at https://globalnews.ca/news/5449602/climate-change-un-jobs-heat/. Retrieved April 28, 2020.

Tiyou, T. (2018). In the state of wind energy in Africa. Africa's Power Journal, March 14, 2018 Edition. Online available at https://esi-africa.com/top-stories/the-state-of-wind-energy-in-africa/. Retrieved May 10, 2020.

Trading economics (2020). Unemployment Rate reported in several countries part of Africa. Online available at https://tradingeconomics.com/country-list/unemployment-rate?continent=africa. Retrieved May 12, 2020

UN Department of Economic and Social Affairs Population Division (2019). Overall total population - world population prospects: 2019 revision. Online available at http://creativecommons.org/... Retrieved May 6, 2020.

UNDP (n.d). Climate change adaptation in West Africa. online available at http://adaptationundp.org/explore/western-africa. retrieved May 7, 2020.

Unicef (n.d). Youth of Africa: Unemployment, social cohesion, and political instability. Online available at https://unicef_irc.org/article/1060-youth-of-africa-unemployment-social-cohesion-and-politicalinstability.html. Retrieved May 11, 2020

United Nations Economic Commission for Africa (n.d). Economic growth, development and climate change in Africa. Geneva: UNECA.

United Nations Framework Convention on Climate Change - UNFCCC (2006). Technologies for adaptation to climate change. Bonn: UNFCCC.

United States Environmental Protection Agency (2017). Climate change science. Online available at https://19January2017snapshot.epa.gov/climate-change-science/causes-climate-change-html. Retrieved April 13, 2020.

Usigbe, L. (2020). Drying Lake Chad basin gives rise to crisis: Food security, conflicts, terrorism, displacement, and climate effects compound challenges. Africa Renewal, Issue Dec. 2019 - March 2020, edition. Available online at https://un.org/africarenewal/magazine/december2019-march2020... Retrieved May 2, 2020.

Wier, M. V. (2019). Major job losses with climate change. Online available at: https://theconversation.com/doclimate-policies-kill-jobs-an-economist-on-why-they-don't-cause-massive-unemployment-106928. Retrieved April 14, 2020.

World Atlas (n.d). Which countries are part of West Africa? Online available at http://worldatlas.com/articles/which-countriesare-part-of-west-africa.html. Retrieved May 6, 2020.

World Bank (2010). Africa rainfall and temperature evaluation system. Washington DC.: World Bank.

World Bank (2014). World development report 2014, risk and opportunity: Managing risk for development. Washington: World Bank. 
World Meteorological Organization - WMO (2017). Reducing climate impacts in West Africa. online available at http://public.wmo.int/en/media/news/reducing-climate-impacts-west-africa. Retrieved May 7, 2020.

Wright, C. Y., Garland, R. M., Norval, M. \& Vogel, C. (2014). Human health impacts in a changing South Africa climate. South Africa Medical Journal, 104(8), 579-582.

Zieba, F. W., Yengoh, G. T. \& Tom, A. (2017). Seasonal migration and settlement around Lake Chad: Strategies for control of resources in an increasingly dry lake. Online available at https://researchgate.net/publication/319299142_seasonal_migration_and_settlement_around_lake_chad... Retrieved May 2, 2020.

Zipay, J. (n.d). A guide to green careers: Make a living, make a difference. Online available at https://www.learnhowtobecome.org/career-resource-centre/green-c... Retrieved April 6, 2020. 